\title{
Geochemical modeling of gold precipitation conditions in the Bloco do Butiá Mine, Lavras do Sul/Brazil
}

\author{
ANDRÉ S. MEXIAS ${ }^{1}$, GILLES BERGER ${ }^{2}$, MÁRCIA E.B. GOMES ${ }^{1}$, MILTON L.L. FORMOSO ${ }^{1}$, \\ NORBERTO DANI ${ }^{1}$, JOSÉ C. FRANTZ ${ }^{1}$ and EVERTON M. BONGIOLO ${ }^{1}$ \\ ${ }^{1}$ Universidade Federal do Rio Grande do Sul, Instituto de Geociências \\ Av. Bento Gonçalves 9500, 91501-970 Porto Alegre, RS, Brasil \\ ${ }^{2}$ Université Paul Sabatier, LMTG, 38 rue des 36 Ponts, 31400, Toulouse, France \\ Manuscript received on June 7, 2004; accepted for publication on February $23^{\text {rd }}$, 2005; \\ contributed by MILTON L.L. FORMOSO*
}

\begin{abstract}
A geochemical modeling of gold deposition was performed using the EQ3/EQ6 software package using conditions inferred from geological, petrographic, geochemical and fluid inclusion data from the Bloco do Butiá gold mine, Lavras do Sul, RS. Gold in the mine occurs only in the pyrite structure (invisible gold). The pyrite occurs associated with white mica (phengite) in the zone of phyllic alteration. The process of gold deposition showed to be related to temperature and $\mathrm{pH}$ decrease. The $\mathrm{pH}$ decrease was fundamental to gold deposition by destabilization of sulfur species $\left[\mathrm{Au}(\mathrm{HS})_{2}^{-}, \mathrm{HAu}(\mathrm{HS})_{2}^{0}\right.$ and $\left.\mathrm{Au}(\mathrm{HS})^{0}\right]$ dissolved in the aqueous solution, being $\mathrm{Au}(\mathrm{HS})^{0}$ the main gold transporting complex. The addition of $\mathrm{KCl}$ is hard to accept as cause of gold precipitation because no $\mathrm{Cl}^{-}$was detected in phengite. However, the geochemical mass balance calculation resulted in the gain of some potassium in the zone of phyllic alteration. The precipitation of pyrite ( \pm auriferous) may have been strongly influenced by iron availability resulting from dissolution of ferrous chlorites by the fluids responsible for phengite deposition. The low salinity in quartz grain fluid inclusions from the propylitized wall rock also indicates the little importance of chlorine as gold transporting agent. Sulfur, and not chlorine, compounds must have dominated the gold transporting complexes in the Bloco do Butiá gold area.
\end{abstract}

Key words: geochemical modeling, gold, pyrite, sulfur, fluid-rock interaction.

\section{INTRODUCTION}

Studies on gold solubility and deposition have been conducted by several authors (e.g. Schenberger and Barnes 1989, Hayashi and Ohmoto 1991, Gibert et al. 1998) because of the importance of their application in geological exploration.

This study reports the numerical results of a

*Member, Academia Brasileira Ciências Correspondence to: André Sampaio Mexias

E-mail: andre.mexias@ufrgs.br simulated interaction of the mineral reactions between a fluid and the rock with gold solubility. The aim is to relate theoretical and natural conditions of gold deposition in the Bloco do Butiá gold mine.

The mineral deposits in the Lavras do Sul region are hosted by Neoproterozoic granitic rocks from the Lavras do Sul Intrusive Complex (Gastal and Lafon 1998) and by volcanogenic rocks from the Hilário Formation. The former comprise a central granodiorite facies, partly assimilated by alka- 
line magma (perthite granite - border facies) that generated hybrid rocks (sieno and monzogranites transitional facies), while the latter is formed mainly by basic to intermediate volcanogenic rocks. The Bloco do Butiá area is located in the perthite granite facies occurring at the western border of the granitic complex (Fig. 1).

The hydrothermal alteration and mineralization occur along one hundred meters long fractures (EW to $\mathrm{N} 70^{\circ} \mathrm{W}$, dipping to $\mathrm{N}$ in high angle), forming centimetric to metric alteration haloes. According to petrographic observations (Mexias et al. 2002, 2004), the hydrothermal alteration began with episyenite formation associated with the leaching of high volumes of silica through faults and fractures. The quartz is dissolved forming vugs, increasing rock permeability and porosity. The amphibole changes into ferrous chlorite, which partially precipitates in these vugs. A stage of phyllic alteration, characterized by neutral to acid fluids and which promoted phengite + pyrite (and gold) precipitation, occurred later in the vugs left by the dissolution of quartz and also promoted the partial dissolution of the previous crystallized iron-rich chlorite. Gold concentrations in the phyllic altered rock are around $1 \mathrm{ppm}$ and are mainly represented as "invisible" gold in pyrite grains. Propylitization is observed as a widespread alteration, characterized by the isovolumetric chloritization of amphibole in the rocks that envelope these highly previous altered and mineralized portions of rock. Weathering processes may have been responsible for a secondary concentration of gold, stimulated by the easy degradation of this porous and permeable, previously altered and phyllosilicate-rich rock.

\section{MATERIALS AND METHODS}

Gammons and Williams-Jones (1997), when studying the gold mobility in porphyry-epithermal systems, observed that at very high temperatures $\left(\geq 500^{\circ} \mathrm{C}\right.$ ) gold is dissolved mainly as $\mathrm{AuCl}_{2}^{-}$complexes showing that its solubility decreases constantly with cooling. At lower temperatures, the authors demonstrated that the dominant complexes change mainly to $\mathrm{Au}(\mathrm{HS})_{2}^{-}$. They stress that the transition temperature of the chloride-bissulphite complexes as main gold transport agents depends on $\mathrm{pH}$ and on the $\mathrm{H}_{2} \mathrm{~S} / \mathrm{Cl}$ ratio of the original fluid, as well as the occurrence or not of boiling in the hydrothermal system.

In our study, assumptions on the factors that can control the gold deposition were tested by using the EQ3/6 software package (Wolery 1983, Wolery and Daveler 1992).

EQ3 performs the chemical speciation of an aqueous solution. It distributes each element of the solution in stable aqueous species, calculates the activity coefficients of water and of the aqueous species, the gas fugacity, and calculates the saturation index of the solution with respect to all phases considered in the database. EQ6 models the mass transfer in a solid-solution-gas system. It approximates irreversible reactions by a succession of small reaction steps. At each step it reacts small amounts of reactants (minerals, aqueous species, or gas), calculates the new composition of the solution, the fugacity of gases, and models the precipitation conditions of over-saturations.

Three kinds of quantitative information can be generated:

- The chemical force, which drives a given reaction (Gibbs Free Energy of the system);

- The nature of the stable paragenesis as a function of the temperature and chemical parameters;

- The time required to reach thermodynamic equilibrium as a function of the specified kinetic laws.

\section{Modeling Procedures}

\section{General characteristics of the theoretical experiment}

The following topics summarize the assumed general characteristics of the theoretical experiment: 


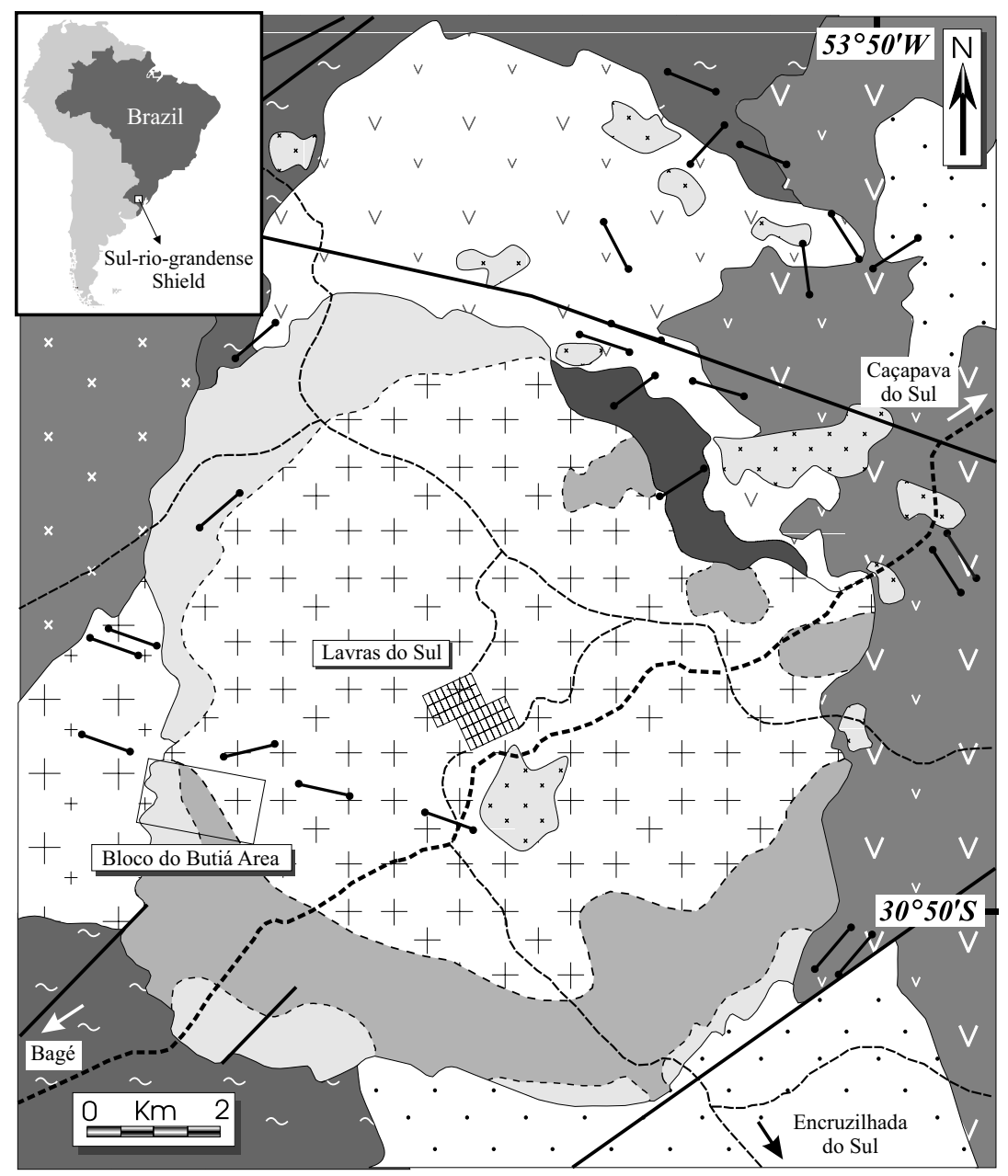

Seival Plutonic Volcano-sedimentary association (Neoproterozoic / Eopaleozoic)

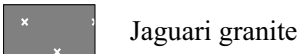

Lavras do Sul Intrusive Complex

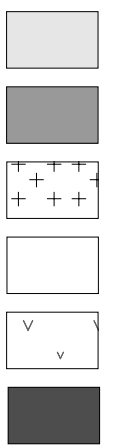

perthite granites

sieno- to monzogranites

monzogranites to granodiorites

quartz monzonites

monzonites

Arroio do Jacques monzodiorite
Palma metamorphic accretionary terrain (medium to low grade / Neoproterozoic)

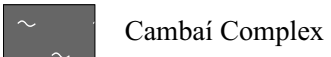

$+\quad$ Fazenda do Posto granodiorite

Volcano-sedimentary sequence of Camaquã Basin

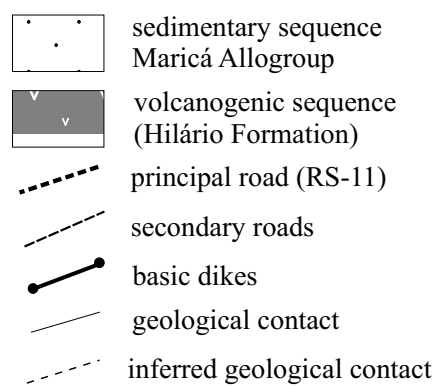

Fig. 1 - Location and geological map of the studied area. Adapted from Gastal and Lafon (1998). 
i. The assumed changes of modeling conditions describe a chemical disequilibrium between the rock and the fluid.

ii. The amount of dissolved primary phases or precipitated secondary minerals required to reach another state of equilibrium was calculated.

iii. The number of secondary phases was limited to the starting paragenesis + magnetite and gold.

iv. The results are expressed in moles of minerals produced or consumed by $1 \mathrm{~kg}$ of solution (see Appendix).

\section{Conditions of fluids}

For the EQ3 modeling calculations, we used an initial fluid of 0.8 molal salinity $(4.8 \mathrm{wt} \%$ eq. $\mathrm{NaCl})$ at $300^{\circ} \mathrm{C}$ with an assemblage of quartz, albite, $\mathrm{K}$-feldspar, muscovite, pyrite, magnetite and gold. This mineral paragenesis corresponds to the minerals formed in the rock during the gold deposition in the phyllic alteration.

The salinity ( $4.8 \mathrm{wt} \%$ eq. $\mathrm{NaCl}$ ) was obtained from aqueous and aqueous-carbonic fluid inclusion data (Mexias 2000, unpublished data). The temperature was set at $300^{\circ} \mathrm{C}$ as this is the minimum crystallization temperature for minerals of hydrothermal origin based on chlorite geothermometry and homogenization temperature from fluid inclusions in quartz grains.

Even if chlorite crystallization is previous to gold deposition in phyllic alteration and the fluid inclusions are in quartz grains near the mineralized (phyllic altered) portions the data is useful in the sense that this temperature is usually reported in active geothermal systems.

Thus, system is balanced after changing several physicochemical parameters such as temperature, $\mathrm{pH}$ and salinity.

The initial gold saturation allows identifying any parameters, which will promote gold deposition in a subsequent modeling step.

In these calculations, the hydrolysis constants of the minerals generated by SUPCRT (Helgeson et al. 1981), were used in combination with the dissociation constants of $\mathrm{Au}(\mathrm{HS})_{2}^{-}, \mathrm{HAu}(\mathrm{HS})_{2}^{0}$ and $\mathrm{Au}(\mathrm{HS})^{0}$ derived by Benchekroun et al. (1996) from thermodynamic properties reported in Schenberger and Barnes (1989) and Hayashi and Ohmoto (1991). The activity coefficients were calculated by using an extended Debuy-Huckel model. The raw data of these results are listed in the Appendix.

\section{RESULTS}

GOLD SPECIATION WITH PH

The modeling of change of gold speciation with $\mathrm{pH}$ was also calculated. Figure $2 \mathrm{~A}$ shows that with decreasing $\mathrm{pH}, \mathrm{Au}(\mathrm{HS})^{0}$ became the principal complexing species of gold. According to figure 2B, the proportion of free gold also increases with decreasing $\mathrm{pH}$. Thus, for a given Au concentration, sulfide and metallic gold will precipitate when the $\mathrm{pH}$ decreases. These results agree with those obtained by Gibert et al. (1998) when studying gold solubility and its speciation in hydrothermal solutions. The authors showed that when the temperature lies between 250 and $400^{\circ} \mathrm{C}$, the main complexing species of gold is $\mathrm{Au}(\mathrm{HS})^{0}$, while when the $\mathrm{pH}$ is $>5.5$, the principal complexing species of gold is $\mathrm{Au}(\mathrm{HS})_{2}^{-}$.

\section{FLUID REACTION WITH THE MINERALS AT} DIFFERENT CONDITIONS OF T $\left(\mathrm{C}^{\circ}\right), \mathrm{H}^{+},(\mathrm{OH})^{-}$ AND KCL ADDITION

Next, an assemblage of quartz, albite, K-feldspar, muscovite, \pm pyrite was put in contact with the fluid previously established. The following conditions were modeled with EQ6.

\section{Temperature variation}

The temperature decrease was modeled from $300^{\circ}$ to $200^{\circ} \mathrm{C}$ (Fig. 3). Figures $3 \mathrm{~A}$ and $3 \mathrm{~B}$ show the evolution of the fluid components in contact with the mineral paragenesis while figures $4 \mathrm{~A}$ and $4 \mathrm{~B}$ present the results of the behavior of this paragenesis and the magnitude of gold deposition. The $\mathrm{pH}$ does not vary considerably, increasing from $5.5\left(300^{\circ} \mathrm{C}\right)$ 


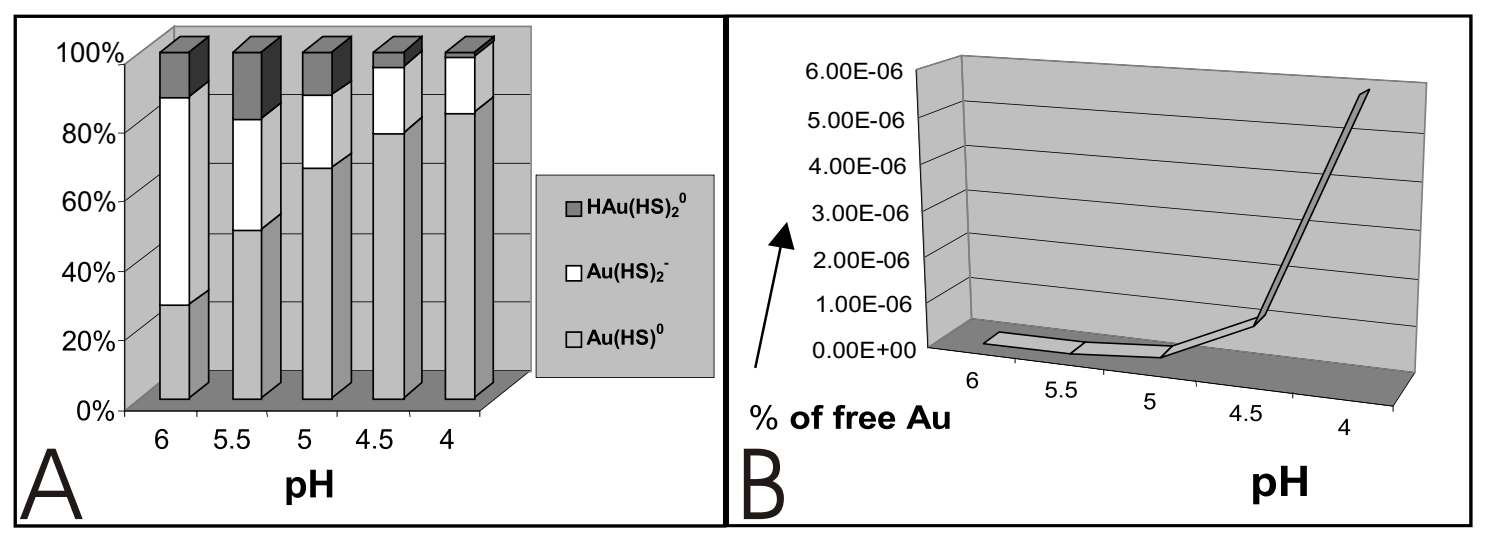

Fig. 2 - Speciation of Au with pH. (A) Variation in the concentration of the complexing sulfides species of gold in mol \% versus $\mathrm{pH}$. (B) Concentrations of free $\mathrm{Au}(\%)$ versus $\mathrm{pH}$.

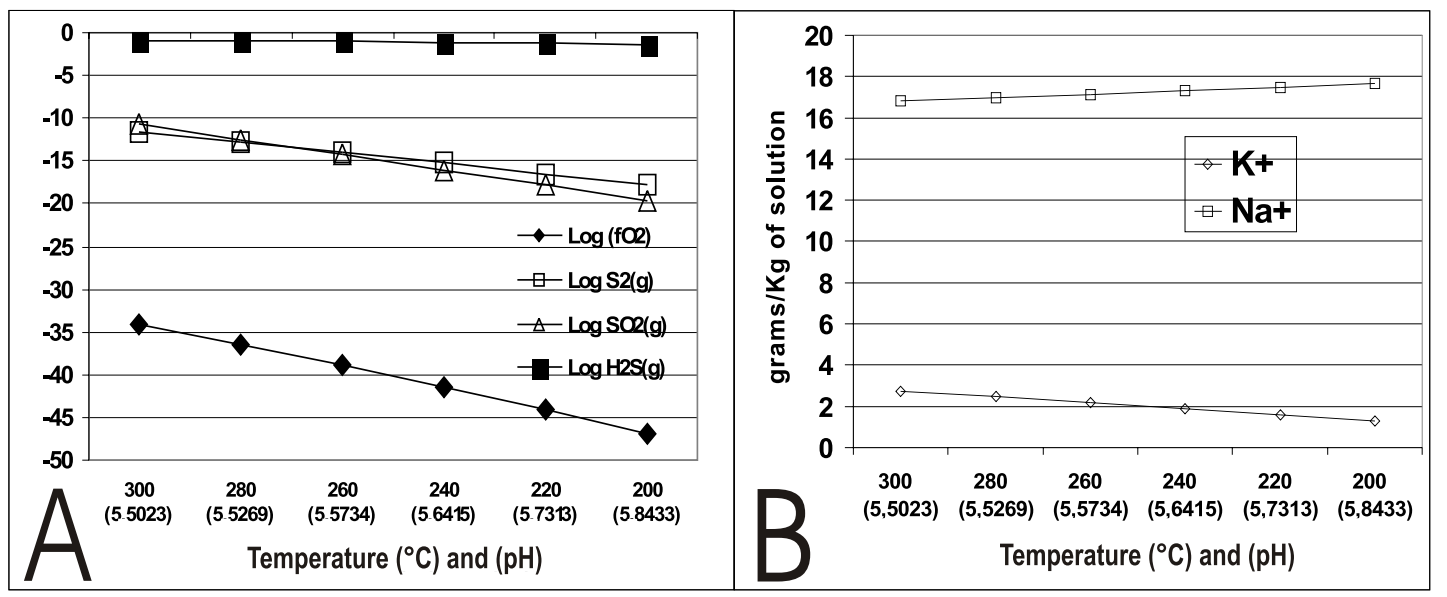

Fig. 3 - Evolution of the fluids components in contact with the mineral paragenesis as a function of temperature decrease from $300^{\circ} \mathrm{C}$ to $200^{\circ} \mathrm{C}$. The $\mathrm{pH}$ of the solution is shown in parenthesis. $\mathrm{A}-\log f \mathrm{O}_{2}, \log \mathrm{S}_{2}(\mathrm{~g}), \log \mathrm{SO}_{2}(\mathrm{~g})$ and $\mathrm{Log} \mathrm{H}_{2} \mathrm{~S}$. B - Concentrations in $\mathrm{g} / \mathrm{Kg}$ in $\mathrm{K}^{+}$and $\mathrm{Na}^{+}$solution.

to only $5.84\left(200^{\circ} \mathrm{C}\right)$, when a certain buffering has been observed.

The fluid shows a decrease in the concentrations of sulfur and $f \mathrm{O}_{2}$. The potassium content in the solution also decreased, while that of sodium increased (Fig. 3A and B). Potassium is consumed in the crystallization of $\mathrm{K}$-feldspar and sodium goes to the solution due to the destabilization of albite (Fig. 4A). The dissolution of albite and the precipitation of K-feldspar, quartz and minor pyrite occurred in all phases of temperature variation. These reac- tions allow the deposition of gold (Fig. 4B), which also occurs associated with variations in other secondary reactions. The sulfur in the solution migrates and forms small quantities of pyrite $(+0.18 \mathrm{~g})$, which can only occur if a small concentration of chlorite is also consumed to supply the required iron $(-0.214 \mathrm{~g})$. If chlorite does not participate in the reaction, pyrite will not precipitate. Therefore, more sulfur will remain in the solution to keep the gold complexed which, in turn, means that gold will not precipitate (see Appendix). 
In the modeled conditions the presence of ferrous chlorite is a fundamental condition for gold precipitation under decreasing temperature.

\section{Acidification and alkalization}

When keeping the temperature at $300^{\circ} \mathrm{C}$, the mineral paragenesis is balanced with the starting fluid under conditions of progressive acidification $\left(\mathrm{H}^{+}\right)$ and alkalization $\left(\mathrm{OH}^{-}\right)$.

In the case of acidification, the addition of $\mathrm{H}^{+}$ does not alter the $\mathrm{pH}$ due to the buffering of the mineral paragenesis. Figures 5A, 5B and 5C show the behavior of the fluid compounds and mineral paragenesis after the addition of $\mathrm{H}^{+}$. Significant variations of $\mathrm{K}^{+}$and $\mathrm{Na}^{+}$were not observed (see Appendix), which is important to buffer the system.

Figure 5A shows a small decrease in $f \mathrm{O}_{2}$ and in $\mathrm{S}_{2}$ and $\mathrm{SO}_{2}$ concentrations. The changes observed in the mineral paragenesis (Fig. 5B) show that the deposition of chlorite consumes iron from pyrite, which is thus slightly destabilized; muscovite is partially dissolved, supplying potassium to crystallize small amounts of K-feldspar; quartz is slightly dissolved, supplying silica needed in the previous reactions; a very small dissolution of albite also provides silica for the previous reactions as well as aluminum for chlorite precipitation; sodium goes to the solution causing a small enrichment in this element (see Appendix).

Due to the partial dissolution of pyrite, the fluid is enriched in sulfur, which associated with excess hydrogen leads to $\mathrm{H}_{2} \mathrm{~S}$ enrichment in the fluid (Fig. 5C). These reactions are stimulated by the addition of $\mathrm{H}^{+}$at $300^{\circ} \mathrm{C}$ and do not result in gold deposition probably because of $\mathrm{pH}$ buffering by the mineral paragenesis and by the absence of pyrite precipitation, which would stimulate the break-down of gold complexes from the sulfur species.

When the solution is alkalized by the addition of $\mathrm{OH}^{-}$, deposition of gold is also observed and, in this case, the $\mathrm{pH}(\sim 5.5)$ seems to be buffered by the mineral paragenesis. There are no changes in concentrations of components and in $f \mathrm{O}_{2}$ of the fluid (see Appendix).
Figures 6A and 6B show the changes of mineral paragenesis (volume and weight variation) during alkalization. The results indicate that the minerals react with each other, with chlorite and $\mathrm{K}$ feldspar being consumed, whereas quartz and muscovite precipitate. While pyrite (and albite) remains unchanged, the iron released by the dissolution of chlorite is used for magnetite formation (Fig. 6A and $6 \mathrm{~B})$.

Finally, the addition of $\mathrm{H}^{+}$or $\mathrm{OH}^{-}$seems not to affect the stability of gold as the $\mathrm{pH}$ is buffered by the mineral paragenesis.

\section{$\mathrm{KCl}$ addition}

In order to evaluate the salinity variation, $\mathrm{KCl}$ was added to the fluid, which was alkalized by the addition of $(\mathrm{OH})^{-}$. The addition of $\mathrm{KCl}$ modifies the cation activity ratio and decreases $\mathrm{pH}$, leading to the precipitation of gold.

The variations of the fluid components are shown in Table I. The $\mathrm{pH}$ decreases (it acidifies: from $\sim 5.5$ to $\sim 4.74)$. The variation of $f \mathrm{O}_{2}, \mathrm{SO}_{2}$ and $\mathrm{S}_{2}$ is smaller and it occurs when $\log \mathrm{mol}(\mathrm{OH})^{-}$ is zero $(1 \mathrm{~mol})$. Nevertheless, $\mathrm{H}_{2} \mathrm{~S}$ increases from 0.12 to 0.13 under these conditions; $\mathrm{K}^{+}$shows high enrichment and $\mathrm{Na}^{+}$has a slight increase. The addition of $\mathrm{KCl}$ obviously leads to potassium enrichment, which will be used in K-feldspar crystallization. In this case, albite is unstable and is dissolved, releasing sodium to the solution (Fig. 7A). These reactions are enhanced with decreasing $\mathrm{pH}$.

Minor reactions occur with other minerals of the paragenesis (Fig. 7B). The modeling begins $\left(\log \mathrm{mol}\right.$ of $(\mathrm{OH})^{-}$from -4 to -3$)$ with a partial dissolution of chlorite and pyrite. Magnetite is added to balance iron. Quartz and muscovite content increases, balancing the decrease of albite and the enrichment of K-feldspar with the alkalization enhancement (Fig. 7A). Pyrite shows relative enrichment, in opposite direction to magnetite, which is depleted. Quartz, muscovite and chlorite are strongly depleted when $\log$ mol of $(\mathrm{OH})^{-}$goes from -1 to 0 . 


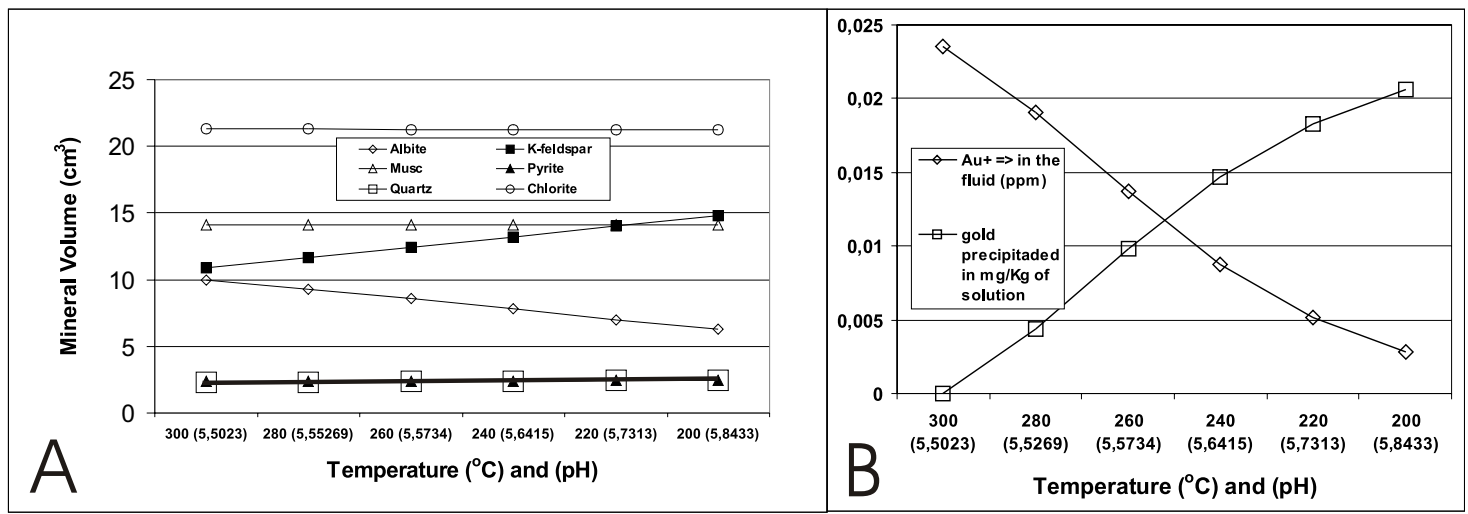

Fig. 4 - A - Volume variation of minerals reacting with the fluid due to temperature decrease. B - Relation of Au+ in the fluid (ppm) vs. gold precipitated ( $\mathrm{mg} / \mathrm{Kg}$ of solution) due to temperature decrease.

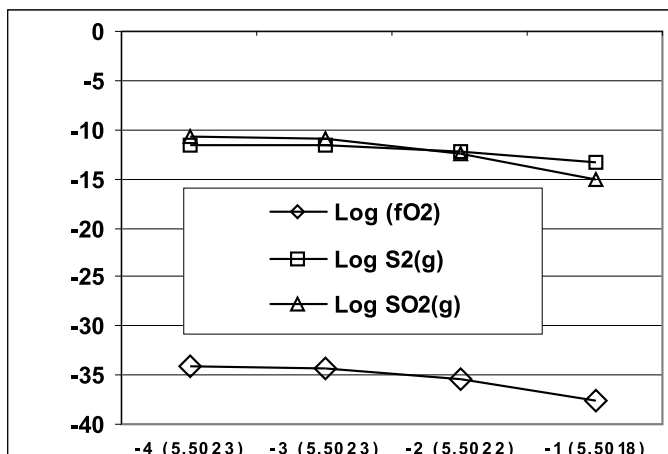

A Acidification at $300^{\circ} \mathrm{C}-\log \mathrm{mol} \mathrm{H}^{+}$and $(\mathrm{pH})$ B

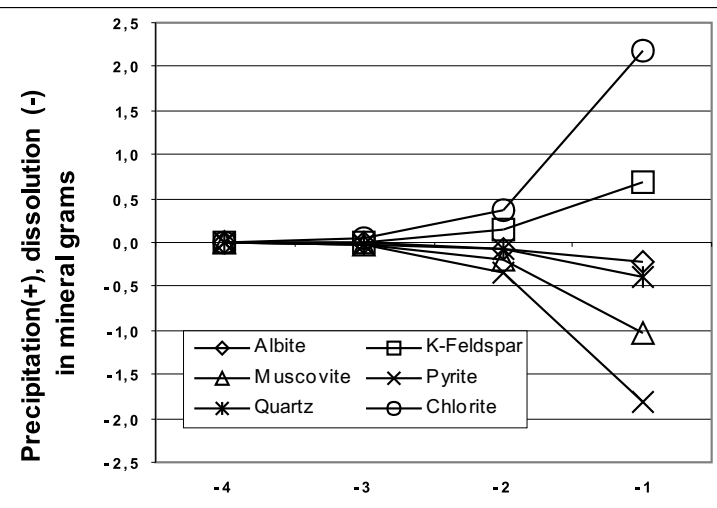

Acidification at $300^{\circ} \mathrm{C}-\log \mathrm{mol} \mathrm{H}^{+}$and $(\mathrm{pH})$

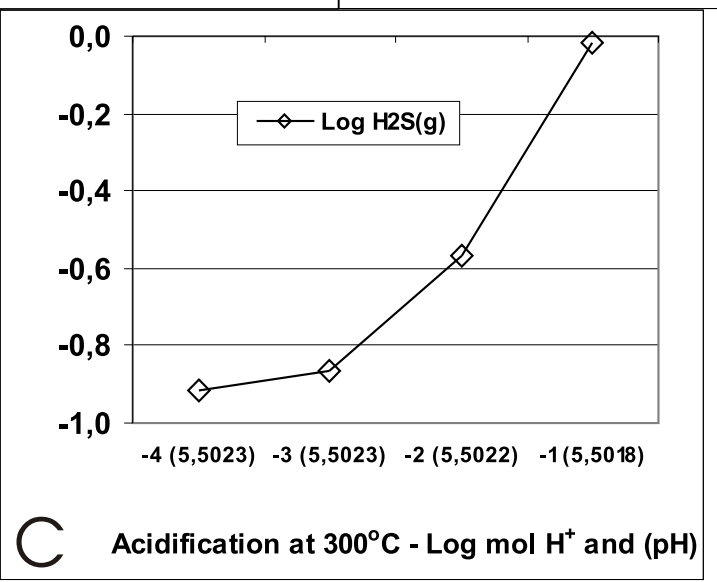

Fig. $5-\mathrm{A}-$ Behavior of the $f \mathrm{O}_{2}$ and of $\mathrm{S}_{2}$ and $\mathrm{SO}_{2}$ (components of the solution), by the addition of $\mathrm{H}^{+}$. $\mathrm{B}-\mathrm{Variation}$ in the precipitated (+) and dissolved (-) concentrations, in grams of mineral, by the addition of $\mathrm{H}^{+}$at $300^{\circ} \mathrm{C}$. C $-\mathrm{Variation}$ of $\mathrm{H}_{2} \mathrm{~S}$ in the fluid, by the addition of $\mathrm{H}^{+}$(gas pressure in bars). 


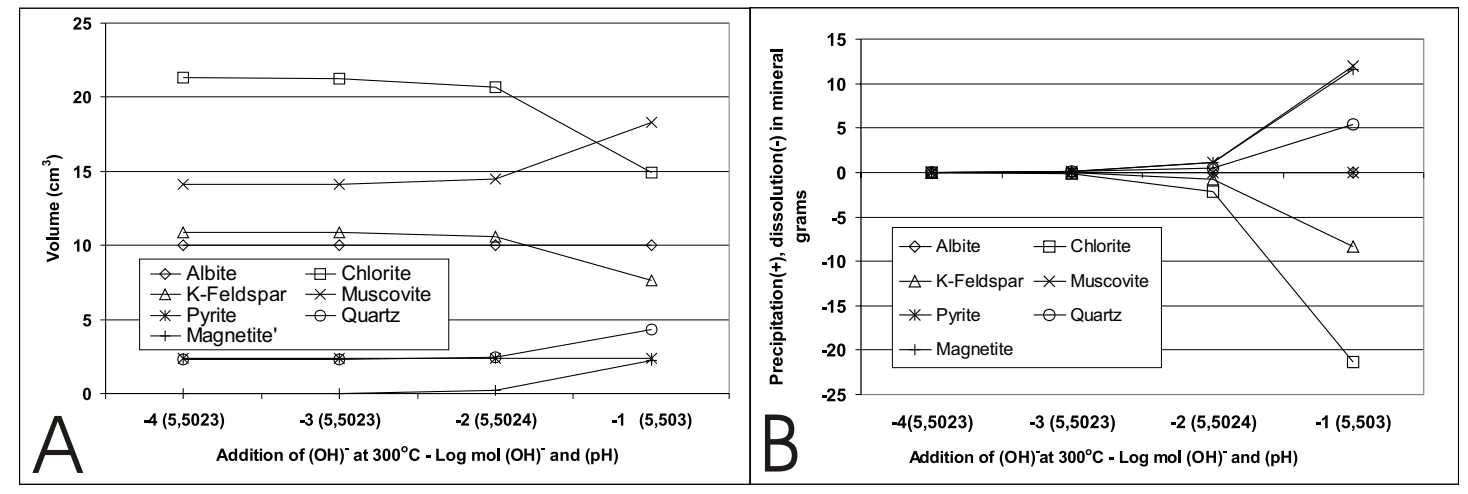

Fig. $6-\mathrm{A}-$ Variation in the volume of minerals of the paragenesis reacting with the fluid by the addition of $(\mathrm{OH})^{-}$at $300^{\circ} \mathrm{C}$ (alkalization). B - Same results as in (A), yet expressed as variations in the precipitated (+) or dissolved (-) concentrations, in grams of minerals.

TABLE I

Variation in the concentration of compounds dissolved in fluid balanced with the mineral paragenesis, with the addition of $\mathrm{KCL}$ and $(\mathrm{OH})^{-}$(alkalization). (Pressure in bars).

\begin{tabular}{c|c|c|c|c|c|c|c}
\hline $\begin{array}{c}\text { Log } \\
\mathrm{Mol}(\mathrm{OH})^{-}\end{array}$ & $\mathrm{pH}$ & $\begin{array}{c}\mathrm{Log} \\
\left(\mathrm{fO}_{2}\right)\end{array}$ & $\begin{array}{c}\mathrm{Log} \\
\mathrm{S}_{2}(\mathrm{~g})\end{array}$ & $\begin{array}{c}\mathrm{Log} \\
\mathrm{SO}_{2}(\mathrm{~g})\end{array}$ & $\begin{array}{c}\mathrm{H}_{2} \mathrm{~S} \\
(\mathrm{~g})\end{array}$ & $\begin{array}{c}\mathrm{K}^{+} \\
\mathrm{g} / \mathrm{Kg} \text { solution }\end{array}$ & $\begin{array}{c}\mathrm{Na}^{+} \\
\mathrm{g} / \mathrm{Kg} \text { solution }\end{array}$ \\
\hline-4 & 5.5023 & -34.0627 & -11.4939 & -10.6523 & 0.116413 & 2.7306 & 16.8085 \\
\hline-3 & 5.502 & -34.0628 & -11.494 & -10.6524 & 0.116413 & 2.7332 & 16.8278 \\
\hline-2 & 5.4991 & -34.0638 & -11.4945 & -10.6537 & 0.116681 & 2.7635 & 17.0148 \\
\hline-1 & 5.4719 & -34.0736 & -11.4999 & -10.6661 & 0.119674 & 3.0638 & 18.9072 \\
\hline 0 & 4.7444 & -34.3454 & -11.6824 & -11.0292 & 0.129927 & 36.3467 & 19.0954 \\
\hline
\end{tabular}

The behavior of precipitated gold follows that of pyrite (Fig. 7C), decreasing abruptly when Log mol of $(\mathrm{OH})^{-}$goes from -4 to -3 and increasing again until $\log$ mol of $(\mathrm{OH})^{-}=0$. Consequently, $\mathrm{Au}^{+}$in solution decreases. In this case, the decrease of $\mathrm{pH}$ and the deposition of pyrite also seem to stimulate gold precipitation.

When comparing these results to conditions found in nature, we are able to associate the modeling with the crystallization of the potassic mineral (phengite) and the dissolution of albite, as well as the acidification with the deposition of auriferous pyrite. In this case, there seems to be a certain relation between the modeled conditions and the petrographic evolution of hydrothermalism. The main difference is that instead of forming K-feldspar as in the modeling, the potassic mineral phase that crystallizes in the altered rock is phengite.

REACTION OF THE FLUID WITH A DIFFERENT PARAGENESIS

This reaction represents the dissolution of $\mathrm{Fe}$ chlorite by a Fe-poor fluid. Gold precipitates with pyrite in response to the decrease of aqueous sulfide.

The reaction of the starting fluid balanced with an iron rich biotite (annite) was simulated in the absence as well as in the presence of pyrite (Table II). The precipitation of gold is higher in the absence than in the presence of pyrite, and there is a great consumption of magnetite, which releases iron. Gold precipitates in the presence of pyrite in response to a decrease of aqueous sulfides, while during the absence of pyrite, the reason for gold precipitation, i. e. the drop in solubility, is probably the 


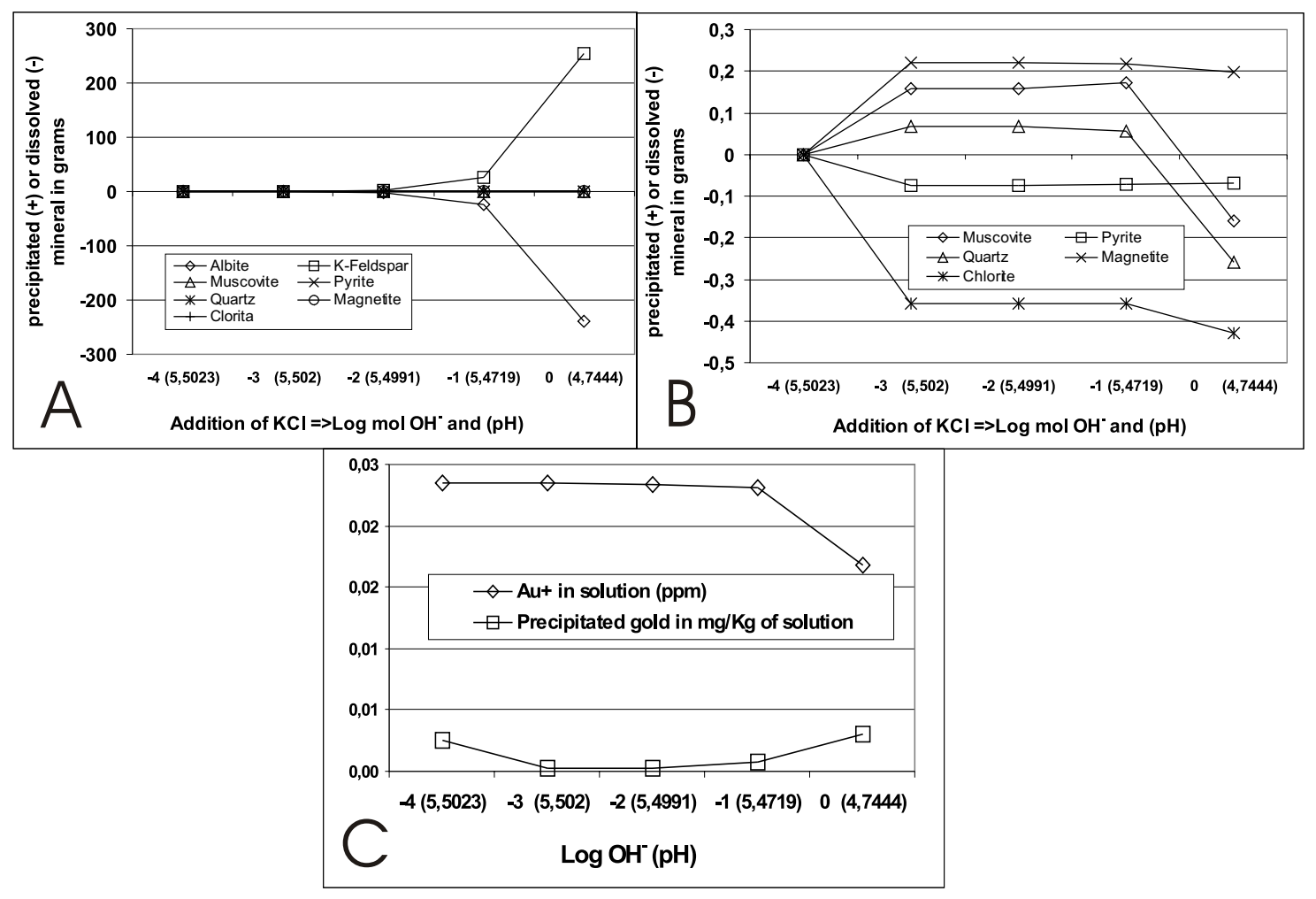

Fig. 7 - A - Variation in the precipitated (+) or dissolved (-) concentrations, in grams of minerals, by the addition of $\mathrm{KCl}$ at $300^{\circ} \mathrm{C}$, with changes in $(\mathrm{OH})^{-}$(alkalization). B - Detail of (A) between $+0,3$ and $-0,5$ grams of mineral. $\mathrm{C}-$ Variation of $\mathrm{Au}^{+}$in solution and precipitated gold ( $\mathrm{mg} / \mathrm{Kg}$ of solution) after the addition of $\mathrm{KCl}$ at $300^{\circ} \mathrm{C}$, with changes in $(\mathrm{OH})^{-}$(alkalization).

TABLE II

Results for the starting fluid in balance with annite.

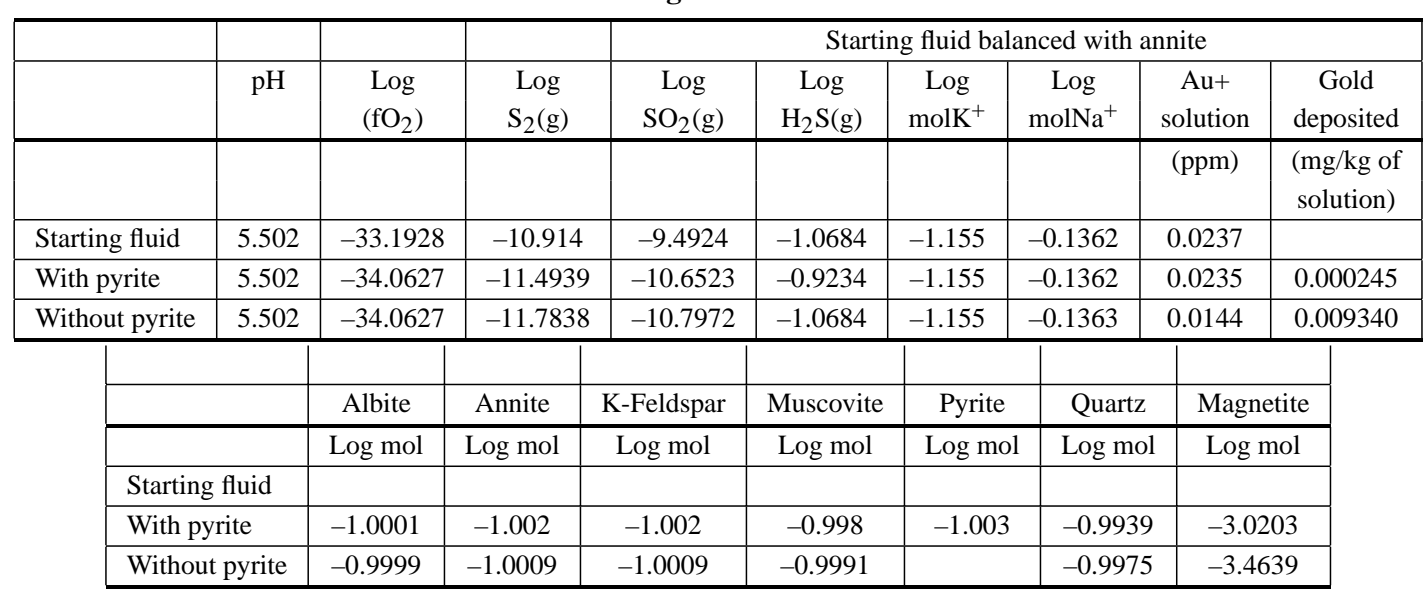


TABLE III

Fluorine and chlorine microprobe analysis in phengitic white mica. Fluorine is present in amounts up to $\sim 1 \%$, yet the concentrations of chlorine are below the detection limit of this method, indicating an absence of micas.

\begin{tabular}{c|c|c|c|c|c|c|c|c|c|c|c|c}
\hline Microanalyses & 1 & 2 & 3 & 4 & 5 & 6 & 7 & 8 & 9 & 10 & 11 & 12 \\
\hline$\% \mathrm{Cl}-$ & 0.025 & 0.004 & 0.007 & 0 & 0 & 0.004 & 0.013 & 0 & 0.001 & 0.01 & 0 & 0.024 \\
\hline$\% \mathrm{~F}-$ & 0.575 & 0.663 & 0.796 & 0.177 & 0.929 & 1.017 & 0.221 & 1.017 & 0.31 & 0.133 & 0.531 & 0.001 \\
\hline
\end{tabular}

consumption of magnetite (iron for annite) and the decrease of $f \mathrm{O}_{2}, \mathrm{~S}_{2}$ and $\mathrm{SO}_{2}$. It seems that in this case the variation in the state of oxidation influenced the gold deposition.

This experiment shows the importance of the silicate phases controlling gold solubility. In the Bloco do Butiá mine biotite is rare and its role in gold deposition is only theoretical.

\section{DISCUSSION AND CONCLUSIONS}

These results show that the processes that led to the deposition of gold are those related to the decrease of temperature and the addition of $\mathrm{KCl}$ (causing $\mathrm{pH}$ decrease). This decrease in $\mathrm{pH}$ showed to be fundamental to gold deposition with sulfur species. The results, when compared with observations in natural samples (presence of phengite and auriferous pyrite), suggest that the decrease of $\mathrm{pH}$ and temperature could stimulate gold precipitation from sulfur complexes. The addition of $\mathrm{KCl}$ is hardly acceptable since no chlorine was detected in phengite (Table III). However, all calculations of the geochemical mass balance had to admit the gain of some potassium in the phyllic alteration, which is the natural stage of gold deposition associated with pyrite. The precipitation of pyrite may have been strongly influenced by iron available from the dissolution of ferrous chlorite by the fluids responsible for phengite deposition.

The low salinities of fluid inclusions in quartz grains of the propylitized wall rock also testify against the importance of chlorine as an agent of gold transport. Therefore, sulfur, and not chlorine, compounds must have dominated the gold complexes.
This dependence of the composition of the sulfur transport complexes from temperature could explain why our theoretical modeling evidenced a greater importance of sulfur, and not chlorine, at $300^{\circ} \mathrm{C}$.

\section{ACKNOWLEDGMENTS}

The authors wish to thank the Coordenação de Aperfeiçoamento de Pessoal de Nível Superior (CAPES) / Comitê Françês de Avaliação da Cooperação Universitária com o Brasil (COFECUB) program 349/01/03 for its financial support.

\section{RESUMO}

Com auxílio dos pacotes de programas EQ3/EQ6 foi realizado um modelamento geoquímico deposicional para ouro e comparado com dados geológicos, petrográficos, geoquímicos e de inclusões fluidas da mina de ouro do Bloco do Butiá, Lavras do Sul/RS. O ouro ocorre na estrutura da pirita (ouro invisível) associado a mica branca (fengita) na alteração fílica. Foi demonstrado que os processos que levam à deposição do ouro são aqueles relacionados ao decréscimo da temperatura e ao abaixamento do $\mathrm{pH}$. O pH também mostrou ser fundamental para a deposição do ouro com as espécies de enxofre $\left[\mathrm{Au}(\mathrm{HS})_{2}^{-}, \mathrm{HAu}(\mathrm{HS})_{2}^{0}\right.$ e $\left.\mathrm{Au}(\mathrm{HS})^{0}\right]$, em razão de potencializar sua desestabilização, sendo $\mathrm{Au}(\mathrm{HS})^{0}$ a principal espécie complexante. A entrada de $\mathrm{KCl}$ é de difícil aceitação como causa da precipitação do ouro visto que não foi identificado $\mathrm{Cl}^{-}$na fengita, apesar de que em todos os cálculos de balanço geoquímico de massa sempre foi necessário admitir a entrada de um pouco de potássio na alteração fílica. A precipitação da pirita ( \pm aurífera) deve ter sido fortemente influenciada pela disponibilidade de ferro de clorita ferrosa, quando da sua dissolução pelos fluidos que depositaram fengita. As baixas salinidades 
APPENDIX

Raw data of the theoretical modeling conditions of gold precipitation from the EQ3/EQ6 software.

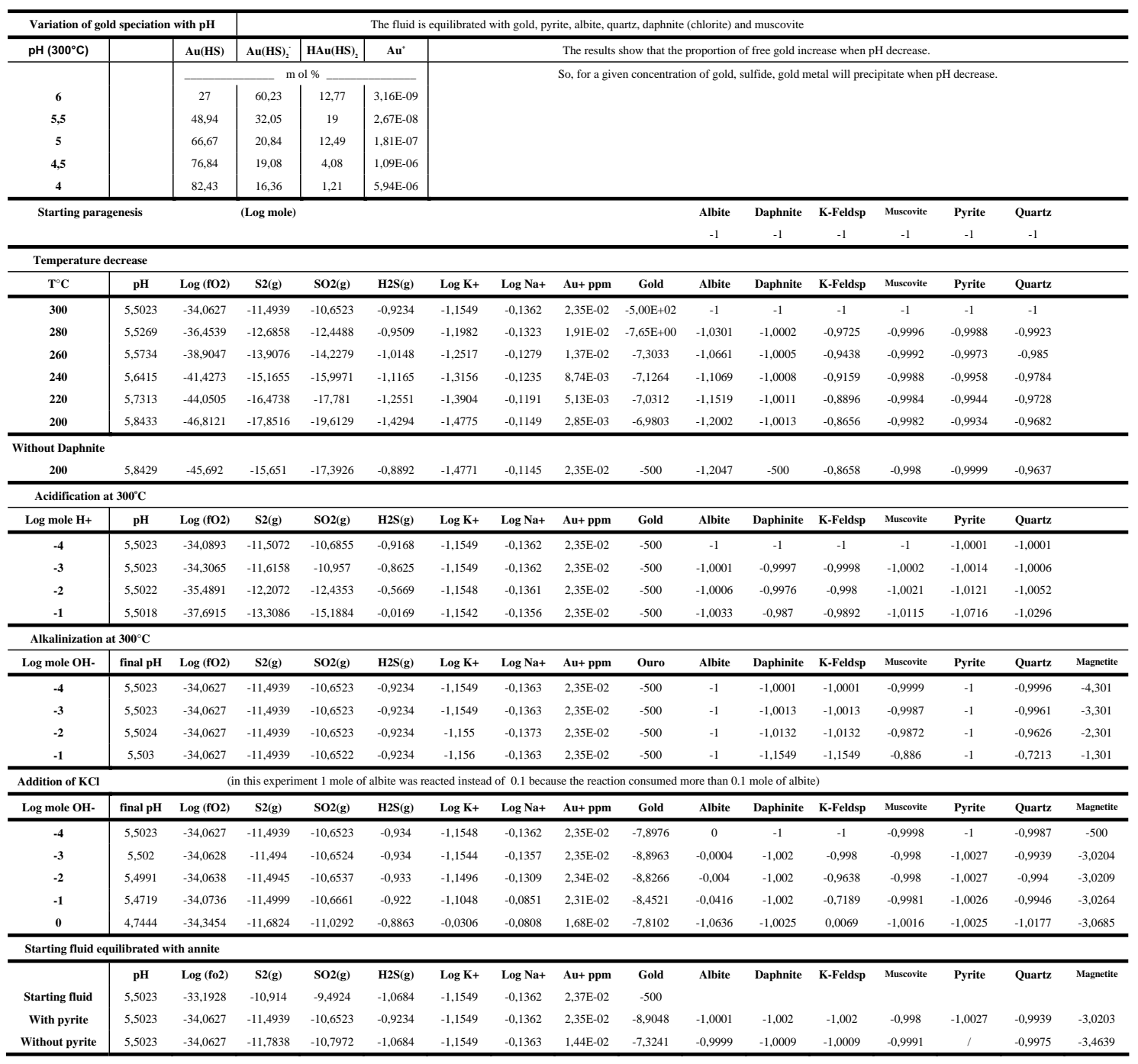


verificadas nas inclusões fluidas dos grãos de quartzo da encaixante propilitizada também advogam para a pouca importância do cloro como agente transportador de ouro. Compostos de enxofre e não de cloro devem ter dominado como complexos transportadores de ouro na área do Bloco do Butiá.

Palavras-chave: modelamento geoquímico, ouro, pirita, enxofre, interação fluido-rocha.

\section{REFERENCES}

Benchekroun F, Berger G and Moine B. 1996. Un modèle minéralogique et chimique du dépôt de l'or dans le gisement de Salsigne (Montagne Noire). CRAS 323: 129-136.

GAMmons CH AND Williams-Jones AE. 1997. Chemical mobility of gold in the porphyryepithermal environment. Econ Geol 92: 45-59.

GASTAL MCP AND LAFON JM. 1998. Gênese e evolução dos granitóides metaluminosos de afinidade alcalina da porção oeste do escudo Sul-riograndense: Geoquímica e isótopos de $\mathrm{Rb}-\mathrm{Sr}$ e $\mathrm{Pb}-\mathrm{Pb}$. Rev Bras de Geocienc 28: 11-28.

Gibert F, Pascal ML and Pichavant M. 1998. Gold solubility and speciation in hydrothermal solutions: Experimental study of the stability of hydrosulfide complex of gold $\left(\mathrm{AuHS}^{\circ}\right)$ at 350 to $450^{\circ} \mathrm{C}$ and 500 bars. Geochim Cosmochim Acta 62: 29312947.

HAYASHI KI AND Онмото H. 1991. Solubility of gold in $\mathrm{NaCl}$ and $\mathrm{H}_{2} \mathrm{~S}$ bearing aqueous solutions at 250$350^{\circ} \mathrm{C}$. Geochim Cosmochim Acta 55: 2111-2126.
Helgeson HC, Kirkham DH and Flowers GC. 1981. Theoretical prediction of the thermodynamic behavior of aqueous electrolytes at high pressures and temperatures: IV. Calculation of activity coefficients, osmotic coefficients and apparent molal and standard and relative partial molal properties to $600^{\circ} \mathrm{C}$ and 5 kb. Amer J Sci 281: 1249-1516.

Mexias As, Gomes MEB, Bongiolo E And ForMOSo MLL. 2002. Perdas e Ganhos Geoquímicos Associados ao Hidrotermalismo da área do Bloco do Butiá - Lavras do Sul, RS. In: CONGRESSO BRASILeIRo DE Geologia XLI. Anais, João Pessoa, PB, Brasil 1: 455.

Mexias AS, Gomes MEB, Bongiolo E And Dani N. 2004. Episyenite as precursors of gold mineralization in Bloco do Butiá Mine - Lavras do Sul/Brazil. In: 32nd International GeologiCAL Congress. Firenze (Italy). Proceedings: CD Rom. Session 8 page 52.

SCHENBERGER DM AND BARNES HL. 1989. Solubility of gold in aqueous sulfide solutions from 150 to $350^{\circ} \mathrm{C}$. Geochim Cosmochim Acta 53: 269-278.

WOLERY TJ. 1983. EQ3NR, a computer program for geochemical aqueous speciation solubility calculations: user's guide and documentation. UCRL53414, Lawrence Livermore National Laboratory, Livermore, California.

Wolery TJ And DAVEler SA. 1992. EQ3/6, A Software Package for Geochemical Modeling of Aqueous Systems. UCRL-MA-110662 PT I-IV. Lawrence Livermore National Laboratory, Livermore, California. 